\title{
Public's Perception of Pharmacy Services during Coronavirus (COVID-19) in Saudi Arabia
}

\author{
Yousef Ahmed Alomi*, (D) Bsc. \\ Pharm, Msc. Clin pharm, BCPS, BCNSP, DiBA \\ CDE Critical Care Clinical Pharmacists, TPN \\ Clinical Pharmacist, Freelancer Business \\ Planner, Content Editor and Data Analyst, \\ P.O.BOX 100, Riyadh 11392, Riyadh, SAUDI \\ ARABIA
}

Sultan Mohammed Al-Jarallah, Head, Ambulatory Care Pharmacy, Oncology and Haematology Clinical Pharmacist,

Pharmaceutical Care Department, Security Forces Hospital, Riyadh, SAUDI ARABIA.

Dona Abdullah Alajmah, Pharm.

D, Batterjee Medical College, Jeddah, SAUDI ARABIA.

Shatha Alhassan Alnami, Pharm. D, Jazan University, Jazan, SAUDI ARABIA.

\section{Correspondence:}

Dr. Yousef Ahmed Alomi, Bsc. Pharm, msc. Clin pharm, bcps, bCNSP, DiBA, CDE Critical Care Clinical Pharmacists, TPN Clinical Pharmacist, Freelancer Business Planner, Content Editor and Data Analyst, P.O.BOX 100, Riyadh 11392, Riyadh, SAUDI ARABIA.

Phone no: +966 504417712

E-mail:yalomi@gmail.com
Received: 28-11-2020;

Accepted: 12-03-2021;

Copyright: () the author(s), publisher and licensee International Journal of Pharmacology and Clinical Sciences. This is an open-access article distributed under the terms of the Creative Commons

Attribution Non-Commercial License, which permits unrestricted non-commercial use, distribution, and reproduction in any medium, provided the original work is properly cited.

This is an open access article distributed under the terms of the Creative Commons AttributionNonCommercial-ShareAlike 4.0 License

Access this article online

\begin{tabular}{|c|c|}
\hline & www.ijpcs.net \\
\hline & DOI: \\
\hline
\end{tabular}

\section{ABSTRACT}

Goal: To exemplify the public's perception of pharmacy services during COVID-19 in Saudi Arabia. Methods: It is three cross-sectional of convenient sampling and calculated number of the subject with power eighty. It was a self-reported electronic survey for the population in the King of Saudi Arabia. It encompassed all citizens who lived in Saudi with age more than 18 years and above. The survey contained of the demographic data patient's perception of medication delivery service during COVID-19. Besides, the patient's experiences of drug information inquiries were linked with the pharmacist during COVID-19. Survey monkey, Microsoft Excel, and Statistical Package of Social Science (SPSS) were used in this study. Results: The total number of responding pharmacists was 461 . Of those, 440 (95.44\%) were Saudi, and $344(74.62 \%)$ were female, with statistical significance between nationality or gender answers $(p<0.001)$. Almost two-thirds of the responders had bachelor's degrees 319 $(69.20 \%)$ with statistically noteworthy between among all academic qualifications $(p<0.001)$. Most of the responders were non-healthcare professionals $338(74.45 \%)$, and physicians and nurses illustrative high percentages 37 (35.92\%) and 31 (30.10\%), respectively, with statistically significant among the remaining answers $(p<0.001)$. The total average scores of patient's perception of medication delivery service during COVID-19 were 2.50. The high scores element was answering drug information inquiries (3.30), medications home delivery (2.80), and requesting medications through a mobile application (2.78). The total average scores of patient's experiences of drug information inquiries communicated with a pharmacist during COVID-19 were 2.76 with high scores element was the drug administration inquiries (3.37). In addition, dosage/ schedule inquiries (3.29) and Pharmacoeconomics/medications cost inquiries (3.18) were also entailed. Conclusion: The public's perception of medication delivery service and experiences of drug information inquiries transferred with the pharmacist during COVID-19 was not optimum. Therefore, targeting a strategic plan of hospital and community pharmacy services during pandemic situations is highly suggested. In addition, further studies of hospital and community pharmacy services individually during a pandemic or emergency public health are mandatory in Saudi Arabia.

Key words: Public, Perception, Pharmacy, Services, COVID-19, Saudi Arabia.

\section{INTRODUCTION}

New viral diseases confronted the countries in the world developed pandemic situations. The World Health Organization called the new virus SARS-2 or coronary viral infection in 2019 or COVID-19. ${ }^{[1,2]}$ All countries were under emergency public health circumstances. Each country offers various health care services nonehealth services to their citizens. Saudi Arabia was one of the perfect countries that delivered differently for their citizens and residents. ${ }^{[3]}$ For health care services, the government has formulated a higher national committee toward this pandemic, organize controlling room buildings to deal with pandemic situations hour by hour and day by day through the Saudi centre for disease control. ${ }^{[3]}$ The command and control administration of Ministry of Health had received all health information about new cases of infection by COVID-19, recovery cases, follow-up cases, hospital admission, critical or death cases. ${ }^{[3]}$ All those cases were familiar through the dashboard and various applications. They were a daily report issued about all previous claims and decisions made accordingly. ${ }^{[3]}$ There were lengthened hospital beds and additional temporary hospitals when needed. Besides, they delivered various COVID-19 vaccines to cover all populations in Saudi Arabia. Numerous pharmacy services are presented through pharmacies by governmental or privates sectors. $^{[1,2]}$ The Saudi Food Drug Authority (SFDA) organized the mask, hand sanitizer with community pharmacies and showed by internet website and application (Sehhaty). Thus, the community pharmacies brought medications and associated products, emphasizing hand sanitizer or alcohol swab through regular dispensing or home delivery services through the internet and mobile applications. ${ }^{[4]}$

Community pharmacies bring medications and associated products, emphasizing hand sanitizer or alcohol swab through regular dispensing or home delivery services through the internet and mobile applications. ${ }^{[4]}$ Recently, the community pharmacy affords immunization services (COVID-19 vaccines) to the patient. The hospital 
pharmacy applied the home delivery and mail pharmacy systems to give the patient medicines. ${ }^{[1]}$ Besides, all pharmacists follow the Ministry of Health guidelines to prevent COVID-19 and international organizations guidelines. ${ }^{[4]}$ Moreover, the pharmacist played an active role in providing enough medication supply at the hospitals or primary care centres, recognised therapeutic management guidelines, and patient education about medications like other countries. ${ }^{[1,2,4,5]}$ Various instruction provided by the local pharmacy society and local investigators encourages the pharmacist to implement the operational activities role during COVID-19. ${ }^{[1,2,5,6]}$ In all the earlier pharmacy services, the patient was the foundation of receiving the benefits. However, patients' perception about pharmacy services during COVID-19, accentuating medication delivery service and drug information inquiry was critical. Few studies were directed about the patient perception of pharmacy services during a pandemic situation of COVID-19 worldwide. ${ }^{[7]}$ However, few or nil studies were conducted about patient's perception of pharmacy services during COVID-19 locally or in Gulf and Arabic countries.

\section{METHODS}

It is a two-month cross-sectional study of the public's perception of pharmacy services during COVID-19 in Saudi Arabia. It was a selfreported electronic survey for the population in the king of Saudi Arabia. It incorporated all citizens who lived in Saudi with age more than 18 years and above. Any incomplete reports or locations outside of Saudi Arabia will be omitted from the study. The survey entailed of demographic data, including locations, gender, material status, age, responder qualifications, occupational status, and monthly income. Further, it includes the second part of the patient's perception of medication delivery service during COVID-19. Besides, the patient's experiences of drug information inquiries were communicated with the pharmacist during COVID-19. The 5-point Likert response scale system was used. The sample was intended according to the previous literature with unlimited population size, a population percentage of $50 \%$, a confidence level of $95 \%$ with $\mathrm{z}$ score of 1.96 , margin of error of $5 \%$, and a drop-out rate of $10 \%$. As a result, the sample size will equal 251 to 432 with a power of study of $80 \% .{ }^{[8-10]}$ The response rate mandatory of calculated sample size at least $60-70 \%$ and above. ${ }^{[10,11]}$ The survey was dispersed through social media and telegram during July and August 2020. The reminder message had been sent every 2-3 weeks. The survey was authenticated through the revision of expert reviewers and pilot testing. Besides, the reliability tests McDonald's $\omega$, Cronbach's a, Guttmann's2, and Guttmann's 6 had been completed with the study. The data analysis is finished through the survey monkey system, the Statistical Package of Social Sciences (SPSS), and Jeffery's Amazing Statistics Program (JASP). Besides, the Microsoft excel sheet version 16 with description and frequency analysis, good of fitness analysis, correlation analysis, inferential analysis of factors marks pharmacists perceptions of forensic pharmacy. The STROBE (Strengthening the reporting of observational studies in epidemiology statement: guidelines for reporting observational studies) steered the reporting of the contemporary study. ${ }^{[12,13]}$

\section{RESULTS}

The total number of responding pharmacists was 461, with most of them coming from the south area $211(45.77 \%)$, and west area 154 (33.41\%) with statistically important among the regions $(p<0.001)$. Of those, $440(95.44 \%)$ were Saudi, and $344(74.62 \%)$ were female, with statistical significance between nationality or gender answers $(p<0.001)$. Most of the responders were in age (18-24) years 174 (39.19\%) with statistically momentous between all ages level $(p<0.001)$. Almost two-thirds of the responders had bachelor's degrees $319(69.20 \%)$ with statistically significant between among all academic qualifications $(p<0.001)$. Most responders were students $186(40.35 \%)$ and employees 144 (31.24\%), and monthly income less than 3,000 SR was $197(46.14 \%)$ statistically significant between among the remaining answers $(p<0.001)$. Most of the responders were non-healthcare professionals 338 (74.45\%), and physicians and nurses illustrative high percentages 37 (35.92\%) and $31(30.10 \%)$, respectively, with statistically significant among the remaining answers $(p<0.001)$. The majority of responders contacted with community pharmacies 282 (62.81\%) or hospital pharmacies 115 (25.61\%) more frequently, while rarely 171 (37.92\%) or sometimes 119 (26.39\%) communicate with pharmacist statistically significant between among the answers $(p<0.001)$. There is a medium positive association between Age (years) and monthly income Kendall's tau_b (0.563) or Spearman's rho (0.677) with statistically significant difference $(p>0.05)$ as discovered in Table 1 and 2.

The total average scores of patient's perception of medication delivery service during COVID-19 were 2.50 . The high scores element was answering drug information inquiries (3.30), medications home delivery (2.80), and requesting medications through a mobile application (2.78). On the contrary, the lowest score was mail medications deliver (1.86). requesting medical devices and instruments through online internet (2.19), screening blood pressure and blood glucose (2.20), and medical apparatus and instruments home delivery (2.22) with statistically significant between answers $(p<0.001)$ as explored in Table 3. The total average scores of patient's experiences of drug information inquiries communicated with a pharmacist during COVID-19 were 2.76 with high scores element was the drug administration inquiries (3.37). In addition, dosage/schedule inquiries (3.29), pharmacoeconomics/medications cost inquiries (3.18), and drug indications inquiries (3.13). On the contrary, the lowest score aspect of the patient's experiences of drug information inquiries was the medication's wastage inquiries (2.09) and alternative medicine inquiries (2.26). Besides, the herbal medicine inquiries (2.33) with statistically significant between answers $(p<0.001)$ as reconnoitred in Table 4 . The reliability test of McDonald's $\omega, 0.954$, Cronbach alpha 0.954, Guttmann's $\lambda 2$, 0.958, and Guttmann's $\lambda 6,0.978$.

Factors persuading the perception of patient's perception of medication delivery service during COVID-19 and patient's experiences of drug information inquiries communicated with a pharmacist during COVID-19. Using independent samples Kruskal-Wallis test and the Bonferroni correction for multiple tests have adjusted significant values, the results showed as follows.

The various factors (location, employment, age (years), nationality, gender, educational level, monthly income, and the responders from healthcare professionals) might bearing the patient's perception of pharmacy services or the patient's experiences of drug information inquiries. However, there are no statically significant differences in influencing the patient's perception of pharmacy services or the patient's experiences of drug information inquiries and those factors $(p>0.05)$. Except, five employment classes affected the patient's experiences of drug information inquiries with the unemployed average score was 2.6500 , and students average score was 3.3109 with statically momentous differences $(p=0.000)$ as explored in Table 5.

The relationship between the patient's perception of medication delivery service during COVID-19 or the patient's experiences of drug information inquiries interconnected with a pharmacist during COVID-19 and factors location, employment, age (years), nationality, gender, educational level, monthly income, and does the responders from a healthcare professional. It confirmed through 


\begin{tabular}{|c|c|c|c|}
\hline Nationality & Response Count & Response Percent & $P$ value \\
\hline Central area & 54 & $11.71 \%$ & \multirow[t]{5}{*}{0.000} \\
\hline North area & 13 & $2.82 \%$ & \\
\hline South area & 211 & $45.77 \%$ & \\
\hline East area & 29 & $6.29 \%$ & \\
\hline West area & 154 & $33.41 \%$ & \\
\hline Answered question & 461 & & \\
\hline Skipped question & $\mathbf{0}$ & & \\
\hline Gender & Response Count & Response Percent & \\
\hline Saudi & 440 & $95.44 \%$ & \multirow[t]{2}{*}{0.000} \\
\hline Non-Saudi & 21 & $4.56 \%$ & \\
\hline Answered question & 461 & & \\
\hline Skipped question & 0 & & \\
\hline Gender & Response Count & Response Percent & \\
\hline Male & 117 & $25.38 \%$ & \multirow[t]{2}{*}{0.000} \\
\hline Female & 344 & $74.62 \%$ & \\
\hline Answered question & 461 & & \\
\hline Skipped question & 0 & & \\
\hline Age & Response Count & Response Percent & \\
\hline$<18$ & 19 & $4.28 \%$ & \multirow[t]{8}{*}{0.000} \\
\hline $18-24$ & 174 & $39.19 \%$ & \\
\hline $25-30$ & 68 & $15.32 \%$ & \\
\hline $31-35$ & 29 & $6.53 \%$ & \\
\hline $36-40$ & 34 & $7.66 \%$ & \\
\hline $41-45$ & 32 & $7.21 \%$ & \\
\hline $46-50$ & 27 & $6.08 \%$ & \\
\hline$>50$ & 61 & $13.74 \%$ & \\
\hline Answered question & 444 & & \\
\hline Skipped question & 17 & & \\
\hline
\end{tabular}

a multiple regression model and considered the patient's perception of pharmacy services delivered dependent variables and factors regarded as expletory variables. As a result, there was a weak relationship $\mathrm{R}(0.102)$ with ( $p=0.816)$ between the patient's perception of pharmacy services delivered. Besides, there was a weak relationship $\mathrm{R}(0.167)$ with ( $p=0.214$ ) between the patient's experiences of drug information inquiries or the patient's experiences of drug information inquiries communicated with the pharmacist during COVID-19 and factors. Therefore, there is no positive or negative relationship between the patient's perception of pharmacy services provided or the Patient's experiences of drug information inquiries communicated with the pharmacist during COVID-19. Furthermore, all factors with non-statistically significant $(p>0.05)$ through multiple regression model and confirmed by Bootstrap model as discovered in Table 6 and 7.

\section{DISCUSSION}

The pharmacy services are snaky in the hospital and community pharmacies in Saudi Arabia and away in the world. ${ }^{[14-18]}$ The hospital pharmacy is increasing in the drug distribution system services and clinical pharmacy services. ${ }^{[17,19,20]}$ However, the community pharmacy is snowballing in the drug distribution system, not in clinical pharmacy services. During COVID-19, numerous drug distribution and clinical pharmacy services variations were altered from a traditional face-to-face delivery system to a fully online system. The drug distribution change to home or might mail delivery. ${ }^{[21-25]}$ The changes encompassed regular prescribing with paper or electronic systems to online internet or applications. As a result, the current study is to to examine the patient's perception of pharmacy services during COVID-19.

The existing electronic legalized with a highreliability survey, dispersed to patients in the south and west region in Saudi Arabia. Most responders came from two areas because the author was working their distribution mainly at their locations. Most of the responders were young females same gender as an author, which is very easy to interaction females than males. Three-quarter of responders was non-healthcare providers, which was our target. However, knowledge of healthcare professionals is desirable to compare with the public one. Most responders communicated with community pharmacies more than hospitals because it was easier to contact and safer during pandemic situations than healthcare institutions.

The average score of patients' perception of pharmacy services did not influence an acceptable level. The patients had a higher perception of pharmacy providing drug information services, medications home delivery, and applications in requesting medications during the COVID-19 period. However, not all community pharmacies carry those services at the same level. It is highly suggested that all community pharmacies apply home delivery with mobile applications for requesting medications or devices. The patients had a poor perception of mail medications delivery because most of the community did not exploit mail pharmacy services. Recently, the $\mathrm{MOH}$ using mail pharmacy services during COVID-19 to deliver the medication to the patient home through Saudi post. ${ }^{[26]}$ The patients had a poor perception of screening of blood glucose or blood pressure done by the pharmacy. Besides, the public responders had a poor perception of home delivery of the medications device or instruments, and community pharmacies did not afford the services for unknown reasons. Recently, the updated pharmacy law permits the community to deliver essential examinations or basic blood glucose or blood pressure, medical devices, public education, and immunization services. ${ }^{[27]}$ Thus, the new approved services will surge patient outcomes, patient satisfaction and declare the role of pharmacists at the community pharmacies.

The existing examination results displayed the patients' experiences of drug information were not good, although all electronic facilities are available. It might be linked to community pharmacy services provided to the patients. Patients during pandemic situations are highly desirable for many healthcare inquiries, and it is up-front for them to contact the community 


\begin{tabular}{|c|c|c|c|}
\hline Responder Qualifications & $\begin{array}{c}\text { Response } \\
\text { Count }\end{array}$ & $\begin{array}{c}\text { Response } \\
\text { Percent }\end{array}$ & \\
\hline Doctorate degree & 18 & $3.90 \%$ & \multirow[t]{8}{*}{0.000} \\
\hline Master degree & 30 & $6.51 \%$ & \\
\hline Bachelor Degree & 319 & $69.20 \%$ & \\
\hline Diploma & 25 & $5.42 \%$ & \\
\hline High school & 56 & $12.15 \%$ & \\
\hline Intermediate School & 12 & $2.60 \%$ & \\
\hline Primary School & 0 & $0.00 \%$ & \\
\hline Not educated & 1 & $0.22 \%$ & \\
\hline Answered question & 461 & & \\
\hline Skipped question & $\mathbf{0}$ & & \\
\hline Occupational status & $\begin{array}{c}\text { Response } \\
\text { Count }\end{array}$ & $\begin{array}{c}\text { Response } \\
\text { Percent }\end{array}$ & \\
\hline Employee & 144 & $31.24 \%$ & \multirow[t]{5}{*}{0.000} \\
\hline Unemployed & 70 & $15.18 \%$ & \\
\hline Student & 186 & $40.35 \%$ & \\
\hline Retried & 57 & $12.36 \%$ & \\
\hline Not written & 4 & $0.87 \%$ & \\
\hline Answered question & 461 & & \\
\hline Skipped question & $\mathbf{0}$ & & \\
\hline Monthly income & $\begin{array}{c}\text { Response } \\
\text { Count }\end{array}$ & $\begin{array}{c}\text { Response } \\
\text { Percent }\end{array}$ & \\
\hline$<3,000 \mathrm{SR}$ & 197 & $46.14 \%$ & \multirow[t]{8}{*}{0.000} \\
\hline $3,001-6,000$ & 33 & $7.73 \%$ & \\
\hline $6,001-9,000$ & 33 & $7.73 \%$ & \\
\hline $9,001-12,000$ & 46 & $10.77 \%$ & \\
\hline $12.001-15,000$ & 49 & $11.48 \%$ & \\
\hline $15,001-18,000$ & 25 & $5.85 \%$ & \\
\hline $18,001-21,000$ & 18 & $4.22 \%$ & \\
\hline$>21,000 \mathrm{SR}$ & 26 & $6.09 \%$ & \\
\hline Answered question & 427 & & \\
\hline Skipped question & 34 & & \\
\hline
\end{tabular}

Continued...

\begin{tabular}{|c|c|c|c|}
\hline $\begin{array}{l}\text { Are you a health care } \\
\text { practitioner (Medical } \\
\text { Doctor- Dentist- Pharmacist- } \\
\text { Nurse- Others? }\end{array}$ & $\begin{array}{l}\text { Response } \\
\text { Count }\end{array}$ & $\begin{array}{l}\text { Response } \\
\text { Percent }\end{array}$ & \\
\hline Yes & 116 & $25.55 \%$ & \multirow[t]{2}{*}{0.000} \\
\hline No & 338 & $74.45 \%$ & \\
\hline Answered question & 454 & & \\
\hline Skipped question & 7 & & \\
\hline $\begin{array}{l}\text { If you are a health care } \\
\text { practitioner, you are a }\end{array}$ & $\begin{array}{l}\text { Response } \\
\text { Count }\end{array}$ & $\begin{array}{l}\text { Response } \\
\text { Percent }\end{array}$ & \\
\hline Physician & 37 & $35.92 \%$ & \multirow[t]{4}{*}{0.000} \\
\hline Nurse & 31 & $30.10 \%$ & \\
\hline Nutritionist & 17 & $16.50 \%$ & \\
\hline Pharmacist & 7 & $6.80 \%$ & \\
\hline Laboratory & 4 & $3.88 \%$ & \\
\hline Radiology & 2 & $1.94 \%$ & \\
\hline Physiotherapy & 3 & $2.91 \%$ & \\
\hline Other (please specify) & 2 & $1.94 \%$ & \\
\hline Answered question & 103 & & \\
\hline Skipped question & 358 & & \\
\hline $\begin{array}{l}\text { Which type of pharmacies } \\
\text { are you more frequent } \\
\text { communication }\end{array}$ & $\begin{array}{l}\text { Response } \\
\text { Count }\end{array}$ & $\begin{array}{l}\text { Response } \\
\text { Percent }\end{array}$ & \\
\hline Hospital pharmacy & 115 & $25.61 \%$ & \\
\hline Community pharmacies & 282 & $62.81 \%$ & \\
\hline Primary healthcare pharmacy & 60 & $13.36 \%$ & \\
\hline Private hospital pharmacies & 38 & $8.46 \%$ & \\
\hline Non & 12 & $2.67 \%$ & \\
\hline Answered question & 449 & & \\
\hline Skipped question & 12 & & \\
\hline $\begin{array}{l}\text { How do you frequently } \\
\text { communicate with the } \\
\text { pharmacist? }\end{array}$ & $\begin{array}{l}\text { Response } \\
\text { Count }\end{array}$ & $\begin{array}{l}\text { Response } \\
\text { Percent }\end{array}$ & \\
\hline Always & 31 & $6.87 \%$ & \multirow[t]{5}{*}{0.000} \\
\hline Most of the time & 54 & $11.97 \%$ & \\
\hline Sometimes & 119 & $26.39 \%$ & \\
\hline Rarely & 171 & $37.92 \%$ & \\
\hline Never & 76 & $16.85 \%$ & \\
\hline Answered question & 451 & & \\
\hline Skipped question & 10 & & \\
\hline
\end{tabular}

pharmacy beside his house. Hotline 937 drug information services are obtainable to answer all medical or pharmacy inquiries at $\mathrm{MOH}$ services. ${ }^{[28,29]}$ However, the community pharmacy is highly commended to provide drug information services and answering drug information inquiries supporting the $\mathrm{MOH}$ services. The cost of drug information services is high. However, the community pharmacy can distribute drug information services through applications or point of sale places. Besides, the patients might use the community pharmacy commutation to answer their inquiries or use the 973 instead of the community pharmacy. ${ }^{[28,29]}$ Most of type drug information inquiries do not variation from the pandemic and regular days. ${ }^{[28]}$ The most common type was drug administration and dosing schedule, while the most minor types of drug information inquiries were drug wastage and herbal or alternative medications because most of public using regular drugs and do not use the herbal drug.
Various factors might move the patient's perception of pharmacy services or the patient's experiences of drug information inquiries during COVID-19 including location, employment, age, gender, nationality, education level, monthly income, and public or healthcare professionals. Not all those factors exaggerated the patient's perception of pharmacy services or experiences of drug information inquiries. There is no statistically significant difference between public or healthcare professionals. There is only redundancy and student more 


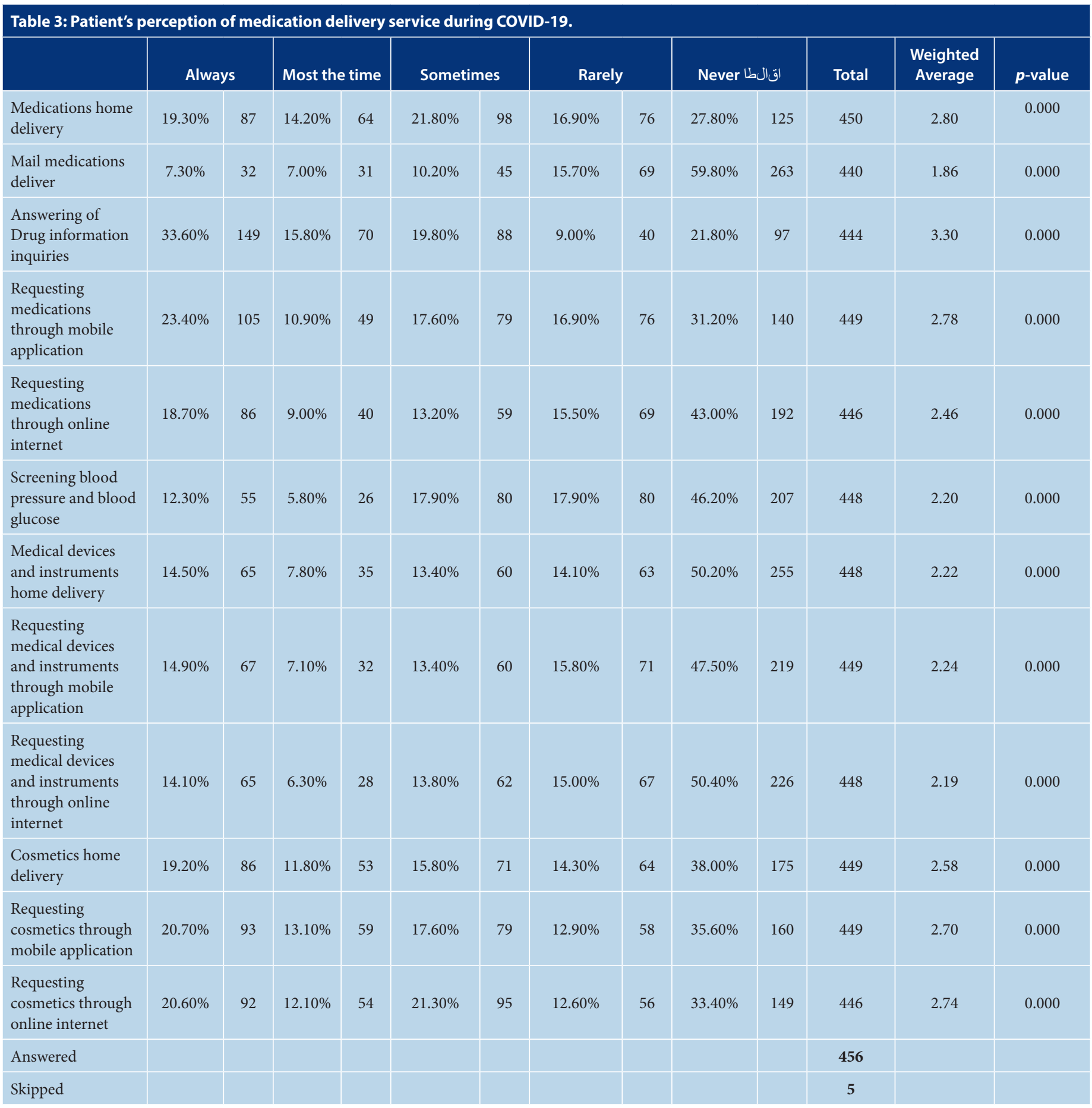

perception of drug information inquiries than other occupational types, which differed from the previous study ${ }^{[7]}$ It is related to demand for drug information during pandemic situations COVID-19. The pharmacy services should be upgraded, emphasizing community pharmacy, including all prescribed or over-the-counter medications or devices, cosmetics, and herbal medications. ${ }^{[24,30-33]}$ It also includes the new implementation of mail pharmacy and using applications or internet drug information during pandemic situations.

\section{Limitations}

Although very informatics information had been reconnoitred from the patient's perception of pharmacy services, numerous limitations encompassed the responder's un-equal distribution in the locations, age, gender, academic qualifications, employment, and monthly income. Besides, the age levels came from females and a young age with student qualifications. Therefore, further studies are necessitated with equal distribution of previous elements.

\section{CONCLUSION}

The public's perception of pharmacy services during COVID-19 in Saudi Arabia highlights the patient's perception of medication delivery. The patient's experiences of drug information 


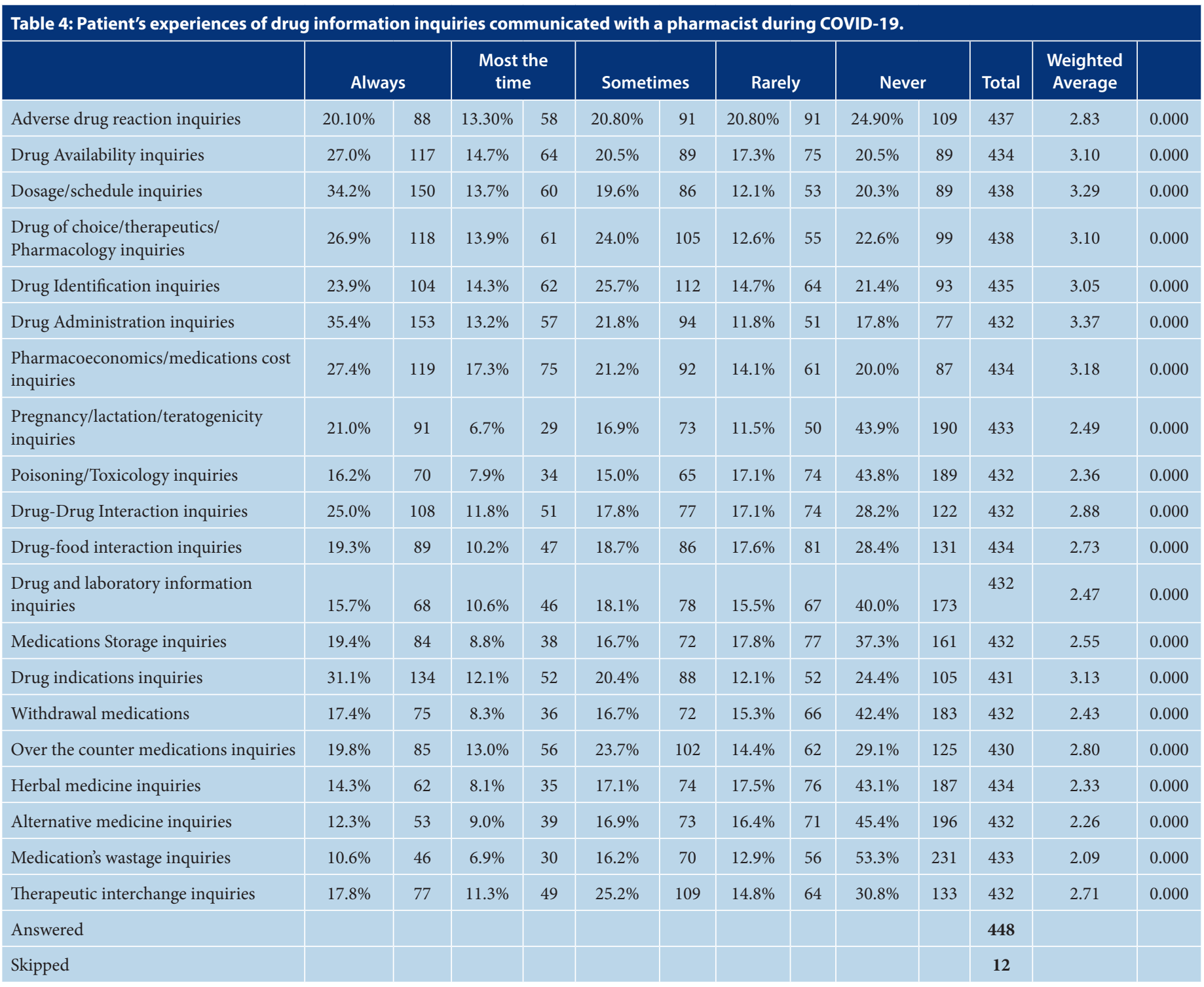

inquiries communicated with the pharmacist were insufficient. There are no differences in the perception between public or healthcare providers in the perception. Therefore, no factors affect the responders of Patient's perception of pharmacy services. More pharmacy applications with drug consultation, medication and devices requesting, and home or mail delivery systems are highly suggested during pandemic situations or emergency public health in Saudi Arabia.

\section{CONFLICT OF INTEREST}

The Authors declare that there is no Conflict of Interest.

\section{Funding}

Non.

\section{Consent for Publications}

Informed consent was obtained from all the participants.

\section{Ethical Approval}

This research was exempted from research and ethical committee or an institutional review board (IRB) approval.

https://www.hhs.gov/ohrp/regulations-andpolicy/decision-charts-2018/index.html

\section{ABBREVIATIONS}

MOH: Ministry of Health; KSA: Kingdom of Saudi Arabia; SPSS: Statistical Package of Social Sciences; JASP: Jeffery's Amazing Statistics Program; Strobe: Strengthening the reporting of observational studies in epidemiology statement: guidelines for reporting observational studies; SFDA: Saudi Food and Drug Authority; CBAHI: Saudi Central Board for Accreditation of Healthcare Institutions.

\section{ORCID ID}

Yousef Ahmed Alomi https://orcid. org/00000003-1381-628X

\section{REFERENCES}

1. Ahmad A, Alkharfy KM, Alrabiah Z, Alhossan A Saudi Arabia, pharmacists and COVID-19 pandemic. J Pharm Policy Pract. 2020;13(1):41. doi: 10.1186/s40545-020-00243-1, PMID 32670595

2. Aburas W, Alshammari TM. Pharmacists' roles in emergency and disasters: COVID-19 as an example. Saudi Pharm J. 2020;28(12):1797-816. doi: 10.1016/j.jsps.2020.11.006, PMID 33257901.

3. Algaissi AA, Alharbi NK, Hassanain M, Hashem AM. Preparedness and response to COVID-19 in Saudi Arabia: building on MERS experience. J Infect Public Health. 2020;13(6):834-8. doi: 


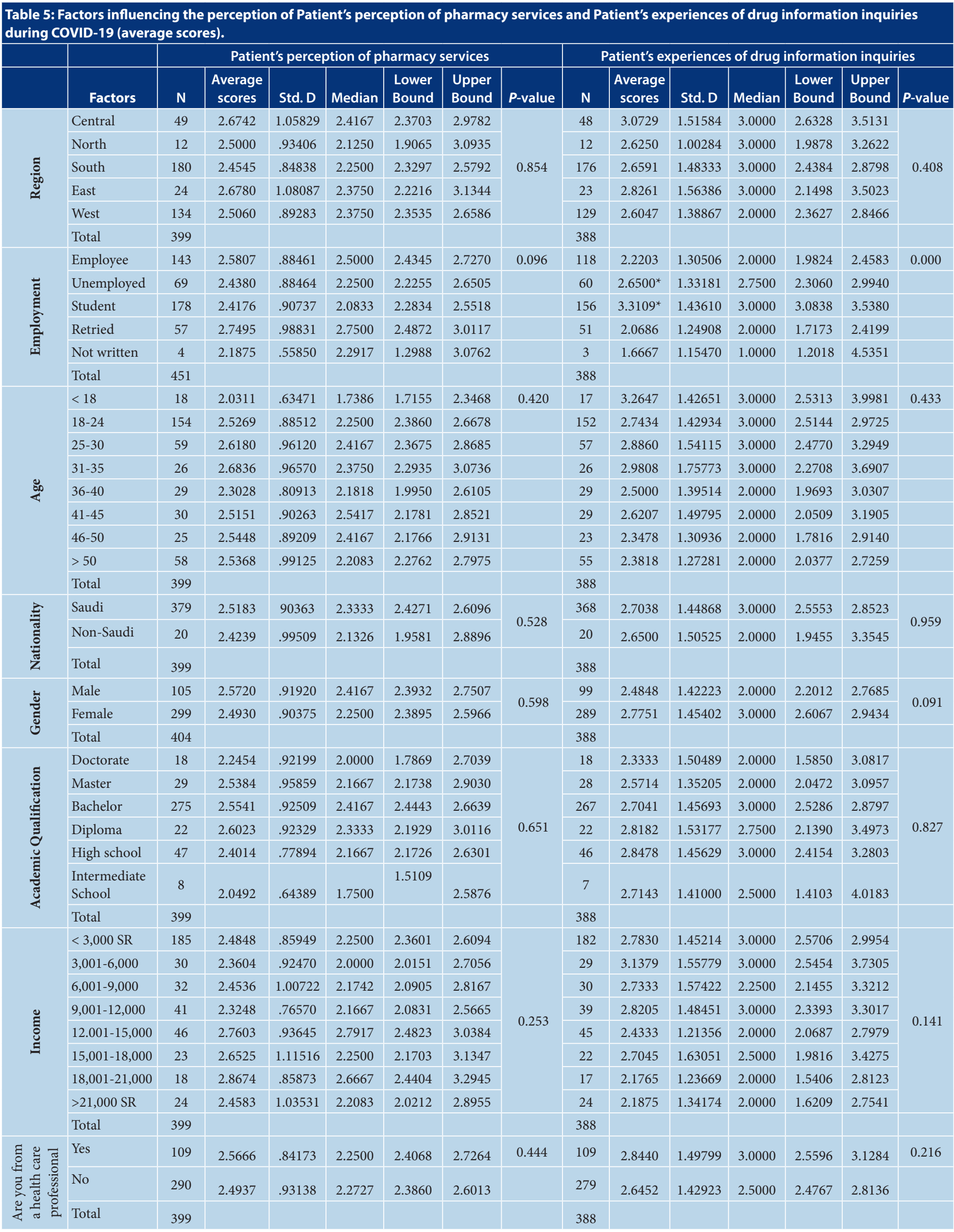




\begin{tabular}{|c|c|c|c|c|c|c|c|c|c|c|c|c|c|c|}
\hline & \multirow[b]{2}{*}{ Model } & \multirow[b]{2}{*}{$\mathbf{R}$} & \multirow[b]{2}{*}{ R Square } & \multirow[b]{2}{*}{$\mathbf{F}$} & \multirow[b]{2}{*}{ Sig. } & \multicolumn{2}{|c|}{$\begin{array}{l}\text { Unstandardized } \\
\text { Coefficients }\end{array}$} & \multirow{2}{*}{$\begin{array}{c}\text { Standardized } \\
\text { Coefficients } \\
\text { Beta }\end{array}$} & \multirow[b]{2}{*}{$\mathbf{t}$} & \multirow[b]{2}{*}{ Sig. } & \multicolumn{2}{|c|}{$\begin{array}{l}95.0 \% \text { Confidence } \\
\text { Interval for B }\end{array}$} & \multicolumn{2}{|c|}{$\begin{array}{l}\text { Collinearity } \\
\text { Statistics }\end{array}$} \\
\hline & & & & & & B & $\begin{array}{l}\text { Std. } \\
\text { Error }\end{array}$ & & & & $\begin{array}{l}\text { Lower } \\
\text { Bound }\end{array}$ & $\begin{array}{l}\text { Upper } \\
\text { Bound }\end{array}$ & Tolerance & VIF \\
\hline \multirow[t]{9}{*}{1} & (Constant) & $.106^{\mathrm{b}}$ & 0.011 & 0.553 & $.816^{\mathrm{b}}$ & 2.832 & .419 & & 6.753 & .000 & 2.008 & 3.657 & & \\
\hline & Location & & & & & $-.017-$ & .038 & $-.025-$ & $-.464-$ & .643 & $-.091-$ & .056 & .862 & 1.161 \\
\hline & Employment & & & & & $-.042-$ & .044 & $-.053-$ & $-.959-$ & .338 & $-.129-$ & .044 & .844 & 1.184 \\
\hline & Age (years) & & & & & $-.004-$ & .029 & $-.011-$ & $-.144-$ & .885 & $-.062-$ & .054 & .447 & 2.235 \\
\hline & Nationality & & & & & $-.068-$ & .215 & $-.016-$ & $-.317-$ & .751 & $-.492-$ & .355 & .943 & 1.060 \\
\hline & Gender & & & & & $-.026-$ & .110 & $-.013-$ & $-.238-$ & .812 & $-.242-$ & .190 & .893 & 1.119 \\
\hline & Educational level & & & & & .005 & .053 & .006 & .101 & .920 & $-.099-$ & .110 & .794 & 1.260 \\
\hline & Monthly income & & & & & .027 & .030 & .068 & .915 & .361 & $-.031-$ & .085 & .455 & 2.200 \\
\hline & $\begin{array}{l}\text { Are you from } \\
\text { a health care } \\
\text { professional }\end{array}$ & & & & & $-.074-$ & .109 & $-.036-$ & $-.674-$ & .501 & $-.289-$ & .141 & .877 & 1.140 \\
\hline
\end{tabular}

a. Dependent Variable: Patients Actual Experiences, Predictors: (Constant), Location, Site of work, Age, Nationality, Gender, Educational level, Monthly income, Are you from the health care professional (Medical Doctor- Dentist- Pharmacist- Nurse- Others),

\begin{tabular}{|c|c|c|c|c|c|c|c|}
\hline \multicolumn{7}{|c|}{ Bootstrap for Coefficients } & \\
\hline & & \multirow[b]{3}{*}{ B } & \multicolumn{5}{|c|}{ Bootstrap $^{a}$} \\
\hline & & & \multirow[b]{2}{*}{ Bias } & \multirow[b]{2}{*}{ Std. Error } & \multirow[b]{2}{*}{ Sig. (2-tailed) } & \multicolumn{2}{|c|}{$\mathbf{9 5} \%$ Confidence Interval } \\
\hline & & & & & & Lower & Upper \\
\hline \multirow[t]{9}{*}{1} & (Constant) & 2.832 & $-.018-$ & .438 & .001 & 1.897 & 3.637 \\
\hline & Location & $-.017-$ & $-.001-$ & .042 & .677 & $-.101-$ & .065 \\
\hline & Site of work & $-.042-$ & .000 & .045 & .368 & $-.130-$ & .044 \\
\hline & Age (years) & $-.004-$ & .000 & .032 & .901 & $-.066-$ & .061 \\
\hline & Nationality & $-.068-$ & $-.001-$ & .246 & .797 & $-.529-$ & .432 \\
\hline & Gender & $-.026-$ & .003 & .109 & .787 & -.248 & .193 \\
\hline & Educational level & .005 & .005 & .053 & .915 & $-.093-$ & .114 \\
\hline & Monthly income & .027 & .003 & .030 & .352 & $-.029-$ & .094 \\
\hline & Are you from a health care professional & $-.074-$ & $-.003-$ & .115 & .533 & $-.306-$ & .130 \\
\hline
\end{tabular}

a. Unless otherwise noted, bootstrap results are based on 1000 bootstrap samples

10.1016/j.jiph.2020.04.016, PMID 32451260

4. Sehhaty on the App Store [Internet]. [cited 2021 Aug 30]. Available from: https://apps.apple.com/ sa/app/-sehhaty/id1459266578

5. Alomi YA, Al-Jarallah SM. Role of Pharmacist in the epidemic, pandemic, and emergency public health with an emphasis on coronavirus Disease (COVID-19). Int J Pharmacol Clin Sci. 2021;10(1):1-5.

6. Badreldin HA, Raslan $\mathrm{S}$, Almudaiheem $\mathrm{H}$, Alomari B, Almowaina S, Joharji $\mathrm{H}$, et al. Pharmacists roles and responsibilities during epidemics and pandemics in Saudi Arabia: an opinion paper from the Saudi Society of clinical pharmacy. Saudi Pharm J. 2020;28(8):1030-4. doi: 10.1016/j. jsps.2020.07.002, PMID 32788836

7. Alhamad H, Abu-Farha R, Albahar F, Jaber D. Public perceptions about pharmacists' role in prescribing, providing education and delivering medications during COVID-19 pandemic era. Int J Clin Pract. 2021;75(4):e13890. doi: 10.1111/ ijcp.13890, PMID 33280210.

8. Charan J, Biswas T. How to calculate sample size for different study designs in medical research? Indian J Psychol Med. 2013;35(2):121-6. doi: 10.4103/0253-7176.116232, PMID 24049221.
9. Pourhoseingholi MA, Vahedi M, Rahimzadeh M Sample size calculation in medical studies. Gastroenterol Hepatol Bed Bench. 2013;6(1):14-7. PMID 24834239

10. Ezhumalai DG. How Big A Sample Do I Require? Annals of SBV. 2017;6(1):39-41. doi: 10.5005/jpjournals-10085-6113

11. Johnson TP, Wislar JS. Response rates and nonresponse errors in surveys [internet]. JAMA. 2012;307(17):1805-6. doi: 10.1001/ jama.2012.3532, PMID 22550194.

12. von Elm E, Altman DG, Egger M, Pocock SJ, Gøtzsche PC, Vandenbroucke JP. The strengthening the reporting of observational studies in epidemiology (STROBE) statement: guidelines for reporting observational studies. PLOS Med. 2007;4(10):1623-7. doi: 10.1371/journal. pmed.0040296.

13. Von Elm E, Altman DG, Egger M, Pocock SJ, Gøtzsche PC, Vandenbroucke JP. The Strengthening the Reporting of Observational Studies in Epidemiology (STROBE) statement: guidelines for reporting observational studies [internet]. Vol. 370: 2007. Available from: http://www.thelancet. com. Available from: http://www.plosmedicine. org [cited 8/25/2021]

14. Alanazi AS, Alfadl AA, Hussain AS. Pharmaceutical care in the community pharmacies of Saudi Arabia: present status and possibilities for improvement. Saudi J Med Med Sci. 2016;4(1):9-14. doi: 10.4103/1658-631X.170881, PMID 30787688.

15. Hughes CM, Hawwa AF, Scullin C, Anderson C, Bernsten CB, Björnsdóttir I, et al. Provision of pharmaceutical care by community pharmacists: A comparison across Europe. Pharm World Sci. 2010 Aug;32(4):472-87. doi: 10.1007/s11096-010 9393-x, PMID 20458539.

16. Jones EJM, MacKinnon NJ, Tsuyuki RT. Pharmaceutical care in community pharmacies: practice and research in Canada. Ann Pharmacother 2005;39(9):1527-33. doi: 10.1345/aph.1E456, PMID 16014374

17. Schneider PJ, Pedersen CA, Scheckelhoff DJ. ASHP national survey of pharmacy practice in hospital settings: dispensing and administration-2017. Am J Health Syst Pharm. 2018;75(16):1203-26. doi: 10.2146/ajhp180151, PMID 29903709.

18. Alomi YA, Jamaan Alghamdi S, Abdullah Alattyh R, Shorog E, Alshahran A, Alasmary S, et al. National survey of pharmacy practice at $\mathrm{MOH}$ hospitals in 


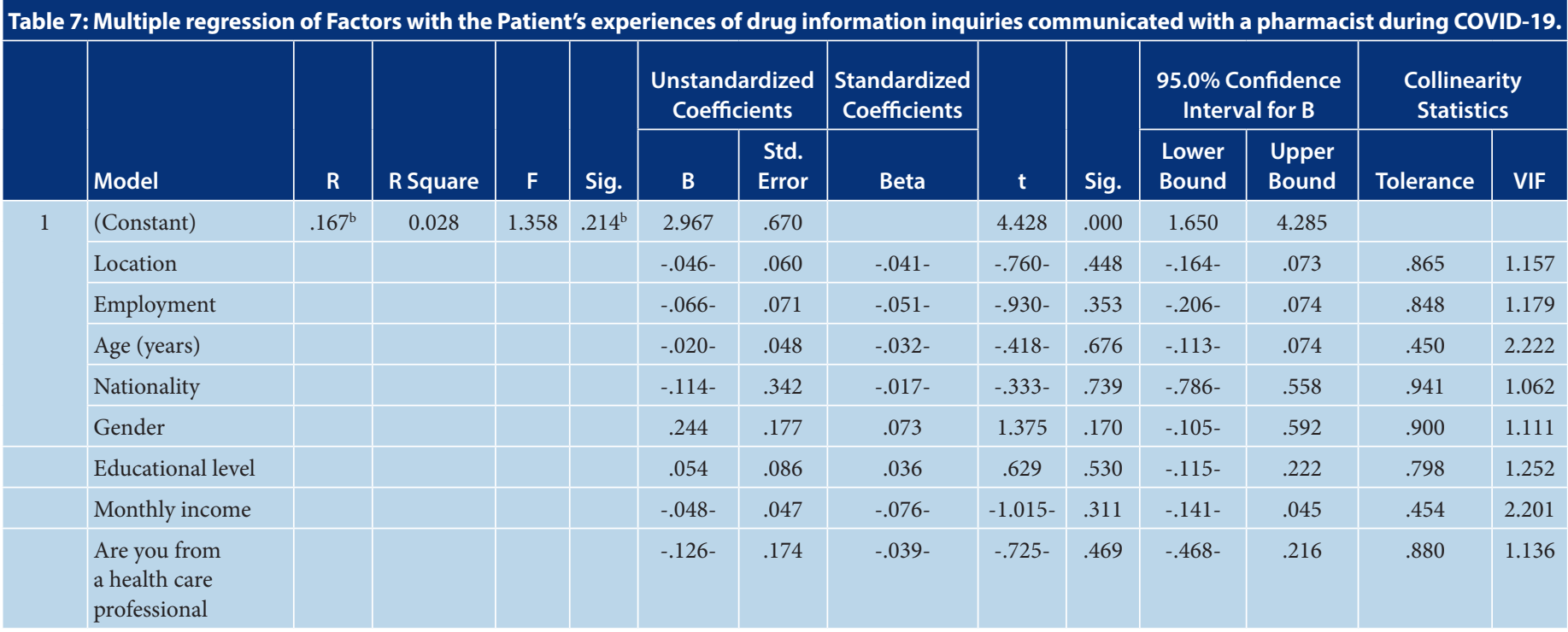

a. Dependent Variable: Patients Actual Experiences, Predictors: (Constant), Location, Site of work, Age, Nationality, Gender, Educational level, Monthly income, Are you from the health care professional (Medical Doctor- Dentist- Pharmacist- Nurse- Others),

\begin{tabular}{|c|c|c|c|c|c|c|c|}
\hline \multicolumn{7}{|c|}{ Bootstrap for Coefficients } & \\
\hline & & \multirow[b]{3}{*}{ B } & \multicolumn{5}{|c|}{ Bootstrap $^{a}$} \\
\hline & & & \multirow[b]{2}{*}{ Bias } & \multirow[b]{2}{*}{ Std. Error } & \multirow[b]{2}{*}{ Sig. (2-tailed) } & \multicolumn{2}{|c|}{$95 \%$ Confidence Interval } \\
\hline & & & & & & Lower & Upper \\
\hline \multirow[t]{9}{*}{1} & (Constant) & 2.967 & $-.035-$ & .628 & .001 & 1.636 & 4.131 \\
\hline & Location & $-.046-$ & .002 & .061 & .442 & $-.163-$ & .076 \\
\hline & Site of work & $-.066-$ & .002 & .069 & .333 & $-.197-$ & .066 \\
\hline & Age (years) & $-.020-$ & $-.001-$ & .047 & .656 & $-.121-$ & .069 \\
\hline & Nationality & $-.114-$ & .003 & .339 & .743 & $-.747-$ & .546 \\
\hline & Gender & .244 & .008 & .171 & .160 & $-.097-$ & .579 \\
\hline & Educational level & .054 & .000 & .086 & .526 & $-.110-$ & .234 \\
\hline & Monthly income & $-.048-$ & .002 & .045 & .283 & $-.138-$ & .047 \\
\hline & Are you from a health care professional & $-.126-$ & .004 & .179 & .487 & $-.471-$ & .228 \\
\hline
\end{tabular}

a. Unless otherwise noted, bootstrap results are based on 1000 bootstrap samples

Saudi Arabia 2016-2017: preparation of medications and dispensing. J Pharm Pract. Commun Med. 2018;4(1s):s54-9.

19. Alomi YA, Shorog E, Alshahrani A, Alasmary S, Alenazi $\mathrm{H}$, Almutairi $\mathrm{A}$, et al. National survey of pharmacy practice at $\mathrm{MOH}$ hospitals in Saudi Arabia 2016-2017: drug monitoring and patients education. J Pharm Pract. Commun Med. 2018;4(1s):s17-22.

20. AlomiYA, Alghamdi SJ, Alattyh RA. National survey of pharmacy practice at MOH hospitals in Saudi Arabia. 2016-2017 : Clinical Pharmacy Services. J Pharm Pr Community Med. 2018;4(1):1S-8S.

21. Kristina SA, Herliana N, Hanifah S. The perception of role and responsibilities during a covid-19 pandemic: A survey from Indonesian pharmacists. Int J Pharmacol Res. 2020;12(2):3034-9.

22. ElGeed H, Owusu Y, Abdulrhim S, Awaisu A, Kattezhathu VS, Abdulrouf PV, et al. Evidence of community pharmacists' response preparedness during COVID-19 public health crisis: A crosssectional study. J Infect Dev Ctries. 2021;15(1):40-50. doi: 10.3855/jidc.13847, PMID 33571144.

23. Hope DL, Day G, Clements J, Hattingh HL. Australian community pharmacists' perceptions of public health before the COVID-19 pandemic. Int J Pharm Pract. 2021;29(3):291-5. doi: 10.1093/ ijpp/riaa010, PMID 33760912

24. Paudyal V, Cadogan C, Fialová D, Henman MC Hazen A, Okuyan B, et al. Provision of clinical pharmacy services during the COVID-19 pandemic: experiences of pharmacists from 16 European countries. Res Social Adm Pharm. 2021; 17(8):1507-17. doi: 10.1016/j.sapharm.2020.11.017, PMID 33288420

25. Mukattash TL, Jarab AS, Mukattash I, Nusair MB, Farha RA, Bisharat $M$, et al. Pharmacists' perception of their role during covid-19: A qualitative content analysis of posts on Facebook pharmacy groups in Jordan. Pharm Pract (Granada). 2020; 18(3):1900. doi: 10.18549/PharmPract.2020.3.1900, PMID 32802216

26. $\mathrm{MOH}$. News - MOH and Saudi post sign agreement to deliver medicines to patients' homes [internet] [cited Aug 5 2021]. Available from: https://www.moh.gov.sa/en/Ministry/Media Center/News/Pages/News-2020-09-01-006.aspx.

27. Pharmacy institutions law. Saudi Food and Drug Authority [internet] [cited Aug 5 2021]. Available from: https://sfda.gov.sa/en/node/74350.

28. Alsharfa A, Albassri $H$, Alonizi K, Alothaian M, Alreshidi M AT. National Drug Information Center Services through Ministry of Health Hotline Calling Center. YA1, Alomi, AL- Mudaiheem. Adv
Pharmacoepidemiol Drug Saf. 2016;937 in Saudi Arabia:5(0):198.

29. Alomi1 YA, Almudaiheem HY. Cost efficiency of national drug information center services through Ministry of Health hotline calling center. In: Saudi Arabia. Int J Pharm Heal Sci. Vol. 937; 2019;2(1). p. 17-20.

30. Auta A, Strickland-Hodge B, Maz J, David S Pharmacist prescribing: a cross-sectional survey of the views of pharmacists in Nigeria. Int Pharm Pract. 2018 Apr 1;26(2):111-9. doi: 10.1111/ ijpp.12381, PMID 28497878.

31. Mccann LM, Haughey SL, Parsons C, Lloyd F, Crealey G, Gormley GJ, et al. A patient perspective of pharmacist prescribing: 'crossing the specialismscrossing the illnesses' Health Expect. 2015 Feb 1;18(1):58-68. doi: 10.1111/hex.12008

32. Gray M, Mysak T. The road to pharmacist prescribing in Alberta Health Services. Am J Health Syst Pharm. 2016;73(18):1451-5. doi: 10.2146/ajhp150786, PMID 27605324.

33. Al-Otaibi F, Soliman Imam M, Abdel-Sattar Ahmed RM, Alotaibi A, Alotaibi A, et al. Pharmacist privilege in Saudi Arabia: pharmacist prescribing and therapeutic interchange. PTB Reports. 2020;6(2):50-4. doi: 10.5530/PTB.2020.6.9 